UDK 782.1(497.12) Gerbið

\title{
NEUPRIZORJENA GERBIČEVA OPERA »KRES«
}

Jože Sive c (Ljubljana)

Slovensko deželno gledališče, ki je bilo svečano odprto v Ljubljani jeseni leta 1892 in je šele omogočilo redno uprizarjanje oper v slovenskem jeziku, ni le važen dejavnik $\mathrm{v}$ rasti naše glasbeno dramatske reprodukcije, ampak mu gre še poseben pomen zato, ker je pospešilo domačo odrsko ustvarjalnost. Zdaj je postala potreba po slovenskih glasbeno scenskih delih bolj živa kot kdajkoli poprej in tako se je $\mathrm{v}$ sorazmerno kratkem času do konca stoletja zvrstilo na odru te ustanove že več domačih opernih novitet: "Teharski plemiči» B. Ipavca (1892) ter "Urh, grof celjski» (1895) in "Ksenija" (1897) V. Parme. ${ }^{1}$

Podobno kot Ipavca in Parmo je ustanovitev Slovenskega deželnega gledališča spodbudila $\mathrm{k}$ odrski tvornosti tudi Frana Gerbiča, skladatelja, ki mu gre še zasluga, da se je dokončno uresničil načrt Dramatičnega društva iz leta 1867, da dobimo Slovenci gledališče, ki bi upoštevalo poleg drame tudi opero.2 Gerbič je bil vse do sezone 1894/95 tesno povezan $z$ delom nove ustanove kot njen prvi kapelnik in tako je lahko še toliko bolj pričakoval uprizoritev svoje stvaritve.

Kdaj je Gerbič začel snovati svojo prvo opero "Kres», točno ne vemo. Nedvomno pa je to moralo biti najkasneje leta 1893, iz katerega izvira prvi podatek o njenem nastajanju. $\mathrm{V}$ pismu $\mathrm{z}$ dne 31 . julija istega leta sporoča svojemu prijatelju, hrvaškemu etnomuzikologu Kuhaču, da piše opero in da mu ta vzame sleherni prosti čas, ki bi mu sicer tu in tam ostal. ${ }^{3}$ Čeprav je bil Gerbič v šoli Glasbene matice in gledališču prezaposlen in zato ni mogel neprekinjeno ustvarjati, pa je delo napredovalo, saj omenja dne 11. februarja 1895 Kuhaču, da je že do polovice gotovo. Zdaj se je skladatelj, ki je sprva gotovo računal na izvedbo v Ljubljani, začel zanimati za nagradni natečaj, ki ga je razpisala uprava Hrvaškega dežel-

\footnotetext{
1 Cvetko D., Zgodovina glasbene umetnosti na Slovenskem III, Ljubljana 1960, 338-341.

2 Cvetko D., ib., 197-200.

3 Franković D., Korespondencija Kuhač-Gerbič, Zagreb 1971, diplomsko delo, tipkopis, 34 ss., cit. pismo kakor tudi ostala, ki jih je Gerbič naslovil Kuhaču, so v gradivu za Kuhačev "Biografski i muzikografski slovnik» v Arhivu JAZU, Zagreb.
} 
nega gledališča za izvirno opero, in hkrati za možnost uprizoritve v Zagrebu. Kaže, da je to $\mathrm{v}$ marsičem $\mathrm{v}$ zvezi $\mathrm{z}$ njegovim bližnjim odhodom iz ljubljanskega gledališča, kjer ga je že $\mathrm{v}$ naslednji sezoni zamenjal kapelnik Hilarij Benišek. ${ }^{4}$ Medtem se je bržkone še povečalo njegovo nezadovoljstvo z razmerami v omenjeni ustanovi, ki ga že nakazuje citirano pismo iz leta 1893 , obenem pa tudi zaostril odnos med njim in upravo. Ker pa je bil Gerbič z opero gotov šele spomladi naslednjega leta - njegova lastnoročna partitura ima na koncu pripisan kot datum dovršitve 5. april $1896^{5}$ —, ta za razpis ni več prišla vpoštev. Ne glede na to je Kuhač izrazil pripravljenost, da poskrbi za izvedbo "Kresa" $\mathrm{v}$ Zagrebu' ${ }^{6}$ in tako je na začetku leta 1898 že dobil pristanek gledališkega intendanta St. Miletića, da se delo uprizori. Kljub temu je stvar padla v vodo. Ko je Miletić odšel na zdravljenje, je Gerbič predal partituro na ogled dirigentu N. Fallerju, ta pa je izvedbo odklonil. Zakaj, iz gradiva ne izvemo, gotovo pa je bila temu vzrok tudi Gerbičeva stvaritev, kar bomo še spoznali v nadaljevanju. Medtem se je Gerbič še pogajal z direktorjem gledališča v Pragi in mu hotel poslati partiturto. Vse kaže, da njegova prizadevanja $\mathrm{v}$ tej smeri enako niso rodila sadu. ${ }^{7}$ Ali je skladatelj potem skušal spraviti opero na oder $\mathrm{v}$ Ljubljani, viri, ki so na voljo, ne povedo, vendar skoro ni verjeti, da ne bi napravil $\mathrm{v}$ ta namen nobenega koraka. Ker pa ni bil zaposlen v gledališču, ni več imel vpliva pri določanju repertoarja in tako tudi ni mogel uveljaviti dela, ki bi ga poprej kot njegov dirigent prav gotovo še lahko.

Libreto za opero "Kres« je napisal Gerbič sam. Ali se je pri tem naslonil na kakšno literarno predlogo, iz virov ni razvidno, vse pa kaže, da si je zgodbo izmislil svobodno. Tudi se ne zdi mogoče, da je snoval svoj libreto pod rahlim vplivom besedila opere $" \mathrm{~V}$ vodnjaku češkega skladatelja V. Blodka, ki so jo leta 1889 uprizorili na odru Dramatičnega društva. ${ }^{8}$ To domnevo sugerira določena motivična sorodnost obeh del. Ta se kaže najprej $\mathrm{v}$ praznovanju Kresa, ki je povezano $\mathrm{z}$ verovanjem $\mathrm{v}$ čarobne moči kresne noči. Tu in tam išče dekle $\mathrm{v}$ emocialni stiski utehe pri stari ženski, ki pomaga $\mathrm{z}$ nasvetom, da bo uzrla $\mathrm{v}$ vodni gladini podobo svojega bodočega ženina. Razen tega še ni prezreti $v$ enem kot drugem primeru prisluškovanja dveh oseb omenjenemu razgovoru, od katerih vsaka zase sklene, da se napoti h kraju skrivnostnega razodetja. ${ }^{\text {Sicer }}$ pa se obe operi vsebinsko ne moreta primerjati že iz preprostega razloga, ker je Gerbičeva resnega, a Blodkova komičnega značaja.

Da bosta razčlenitev in ocena libreta bolje razumljiva, se seznanimo najprej v kratkem $\mathrm{z}$ vsebino opere.

Prvo dejanje. - Sredi razigranih priprav na Kres se pojavi v družbi vaških fantov in deklet stara Barba, ki zbudi pozornost, saj vé marsikatero

\footnotetext{
4 Cvetko D., ib., 340.

5 To partituro hrani Slovenski gledališki muzej v Ljubljani.

6 Prim. Kuhačeva korespondenca, Arhiv Hrvatske, knj. X. št. 174, 21. V. 1896.

7 Prim. Kuhačeva korespondenca, Arhiv Hrvatske, knj. XI., št. 169, 182, 190, 19. I., 9. III. in 26. V. 1898.

8 Cvetko D., ib., 198.

9 Samec S., Operne zgodbe, Ljubljana 1974, 554-555.
} 
skrivnost. Zato jo poprosijo, naj jim pove o moči kresne noči. Barba rada ustreže in razodene, da uzre o polnoči ob luninem svitu deklica v vodi svojega ženina in fant $\mathrm{v}$ ribjem očesu ođisev podobe svoje neveste. $\mathrm{V}$ veseli družbi je tudi kmečko dekle Zorka. Zorka žaluje za svojim Stankom, ki je odšel v vojsko, in je vsa $\mathrm{v}$ skrbeh, da ga ji ne bi speljala mlada vdova in krčmarica Cilja. V stiski se zateče k Barbi, ki jo tolaži in ji svetuje, naj gre o polnoči na brv ob križpotju pod hribom, kjer bo $\mathrm{v}$ vodni gladini zagledala podobo bodočega ženina. Razgovoru prisostvujeta, skrita za prizoriščem, tudi Stanko, ki se je pravkar vrnil domov, in Cilja, ki bi si hotela za vsako ceno priboriti Stanka. Ko zvesta za skrivnost, se oba odločita, da bosta o polnoči na omenjenem kraju. Kmalu nato se pojavi na prizorišču kovač Janez in trka na vrata krčme. Ker je fantu zala krčmarica všeč, jo je prišel povabit na ples. Vendar ga ta posmehljivo zavrne $s$ pripombo, da se krčmarija in kovačija slabo ujemata, Dejanje se zaključi $\mathrm{z}$ veselo pesmijo in rajanjem ob pogledu na kresove, ki so vzplamteli na bližnjih gričih.

Drugo dejanje. - Fantje v kresni noči veselo pričakujejo dekleta, da bi skupno proslavili praznik. Ko ta pridejo, se vsi skupaj odpravijo v g goščavo po suhljad. Le Peter, mladi vdovec in Zorkin stric, ne gre z njimi; ostane sam in meditira o domovini. Kmalu se mladina vrne in kovač Janez zaneti grmado. Sledi veselo proslavljanje ob ognju s pesmijo in plesom. Nazadnje se fanti in dekleta še gredo družabno igro golobnjak. Ko Zorka konec igre dopolnjuje $\mathrm{z}$ izročilom pesmi o jastrebu in gadu, ki umorita golobico oziroma deklico in $\mathrm{s}$ tem aludira na Ciljo kot na tisto žensko, ki ji hoče ugonobiti ljubezensko srečo, se med tekmicama vname prepir. Zdaj je zabava prekinjena in Zorka prebere pismo, $v$ katerem Cilja natolcuje, da je Zorka Stanku nezvesta. Cilja, ki izpoveduje, da Stanka vroče ljubi, sicer noče priznati, da je to pismo, ki je brez njenega podpisa, napisala ona, vendar ima Zorka za to dokaz, saj dobro pozna njeno pisavo in razen tega tudi pečat kaže, kje je bilo pismo oddano. Ko fantje in dekleta to vidijo, potegnejo z Zorko in obsodijo zlobno nakano Cilje.

Tretje dejanje. - Tudi rusalke in kresnice se vesele kresne noči in plešejo in prepevajo ob reki. Ko izginejo, pride $\mathrm{k}$ mostu najprej Stanko, ki silno hrepeni za Zorko in jo je pripravljen tudi braniti pred zlobno in ljuobsumno Ciljo. Kmalu se $\mathrm{v}$ daljavi zaslišijo koraki bližajoče se Zorke in Stanko se skrije pod most, kjer je priklenjen čoln. Ko o polnoči stopi Zorka na usodno mesto in maha s praprotjo nad vodo, da bi v njej videla podobo svojega ljubega, plane nanjo iz zasede Cilja in jo hoče pahniti v vodo. Med borbo se odlomi ograja mostu in obe padeta $\mathrm{v}$ vodo. Zorko reši Stanko, krčmarica pa utone.

Kot je razvidno iz sinopsisa, gre za dva vsebinska momenta: priprave za Kres in samo kresovanje ter ljubezenski trikotnik enega moškega in dveh žensk, ki tega ljubita. Pri tem je dal avtor očitno večji delež ljudskemu slavju kot pa sami dramski zgodbi, ki zato ne more priti dovolj do izraza. V skladu s takšno zasnovo so predvideni številni nastopi zbora, ki pa je kot nosilec slavja predvsem dekorativni element, le redko komentira dejanje in še manj vanj posega. Da je lahko na ta način dosežena 
neka scenska pestrost, sicer ni zanikati, vendar je posledica omenjenega koncepta nedramatičen libreto, ki vsebuje le malo dogajanja in ne pozna pravega viška. Nasploh je libreto $\mathrm{v}$ osnovi dramaturško tako slab, da se zdi predelava nemogoča. Pri tem se toliko bolj čudimo Gerbičevi nekritičnosti, saj je bil človek gledališča in bi lahko vedel, da mora dober tekst sloneti vsaj na osnovnem principu drame: uvod, postopen zaplet, vṛh, razplet in konec. Žal pa se to zaporedje odvija $\mathrm{v}$ njegovem libretu le medlo in nejasno.

$\mathrm{Z}$ dramaturškega vidika je še najbolj zadovoljivo prvo dejanje, kjer zvemo za glavne protagoniste in zaslutimo zaplet drame: Zorka in Cilja ljubita Stanka, ki se vrne $\mathrm{z}$ vojske. Cilja bo skrivoma sledila Zorki k reki, da bi uzrla svojega ženina. Ta del še nudi možnost, da bi bila fabula $v$ nadaljevanju boljše izpeljana in bolj prepričljiva. Ko $v$ drugem dejanju fantje in dekleta že kresujejo, se zdi zaostritev konflikta preveč umetno narejena, neinventivna in dramsko neefektna. Zorkino namigavanje na Ciljo $\mathrm{v}$ zvezi s koncem družabne igre kakor tudi njena obtožba tekmice sta nekako "privlečena za lase" in premalo utemeljena. Vsekakor bi bilo bolj realno, ko bi se tu s pismom pojavil Stanko in obtožil Zorko nezvestobe. Tretje dejanje in zaključek nista logična izpeljava prejšnjega dela - le-ta bi lahko tudi izostal, ne da bi to kaj vplivalo na izid drame -, temveč le izvršitev odločitve iz prvega dejanja. Vsaj tu bi moral Gerbič soočiti vse tri glavne protagoniste, da bi rešil, kar se rešiti dá. Tako pa je konec teatraličen in nerealen.

Od nastopajočih oseb sta $v$ libretu še najbolje karakterizirani Zorka in Cilja, a še ti v odnosu do objekta svoje ljubezni in v izrazito belo-črni tehniki. Medtem ko je Zorka utelešenje čiste, nedolžne ljubezni in potrpežljivo čaka vrnitve svojega dragega, je Cilja polna plamteče strasti in se ne ustraši nobenega sredstva za dosego zaželenega cilja. Zlasti ta strastna narava ženske, ki je pripravljena tudi z zločinom uresničiti svoje načrte, bi morala biti bolj emocionalno utemeljena. Za razliko od Zorke in Cilje je glavna moška figura Stanka bleda in neizrazita. Stanko, nežno hrepeneči ljubimec, nastopa takorekoč le za kulisami in se pojavi na koncu kot wdeus ex machinaw. Ostale osebe nastopajo le epizodno in le tu in tam nakažejo kako svojo potezo, tako da je njih karakterizacija kot značajev komaj mogoča. Končno moti v libretu tudi večkrat neprimeren jezik, kar pa je še sorazmerno najmanjša hiba, saj bi se jo kaj lahko dalo odstraniti. Verzi so dokaj konvencionalni, vsebinsko prazni, nepoetični ali celo neestetski in vulgarni. Tudi besedni zaklad, ki ga avtor uporablja, je reven in banalen. Mestoma imamo vtis, da se je $\mathrm{v}$ nekem smislu ravnal po starem načelu: "Prima la musica e poi le parole» in da je še naknadno dodajal besede, samo da bi s tekstom izpolnil melodijo.

Gerbič je imenoval "Kres« romantično dramatično opero, vendar je naziv le deloma utemeljen. Da je oznaka "romantična» na mestu, ni ugovarjati, saj je takšen že v marsičem sujet, ki vključuje ljudske običaje in obredja, nastop pravljičnih bitij in element čarobno skrivnostnega. Seveda pa ne moremo soglašati $z$ drugo oznako, saj je $v$ libretu dramatika 
v ozadju. Zato bi bil spričo prevladujoče liričnosti bolj ustrezen naziv lirična opera.

Ko se je Gerbič lotil uglasbitve «Kresa», je ustvaril že vrsto izvrstnih zborov in samospevov s klavirsko spremljavo, kantati "Slovo" za moški zbor, četverospev in orkester in "Ave Marija za zbor, dve violini in orgle ter dva samospeva z orkestrom (Ein Friedhofbesuch, Valse concertante).10 To kaže, da je imel dosti več izkušenj na področju malih kot večjih vokalnih oblik. Vendar je važno, da je obvladal orkestralni stavek in znal spretno povezovati glasove in instrumente. ${ }^{11}$ Razen tega je bil Gerbič tedaj že skladatelj z utrjenim umetniškim konceptom in ustaljeno stilno orientacijo. V svojih delih je poudarjal slovanski oziroma slovenski izraz, medtem ko se je razvojno že povzpel iz zgodnje $\mathrm{v}$ visoko fazo romantike. Od velikih sodobnikov sta mu bila najbližja Smetana in Dvořák, ki ju je "ljubil kot očeta». Zelo pa je občudoval Wagnerja, s čigar načeli je povsem soglašal. ${ }^{12}$ Bil je široko razgledan glasbenik, ki je kot gledališki pevec in dirigent dobro poznal klasično in sočasno operno literaturo.

S tem, da si je Gerbič sam spesnil libreto, si ni napravil usluge in bolje bi bilo, ko bi mu stal ob strani literarno vešč sodelavec. Gerbič očitno ni imel literarne sposobnosti in daru, seveda ni mogel napisati besedila, ki bi zajamčilo uspešno opero kot celostno umetnino. Čeprav mu libreto ni dajal možnosti, da bi v kompoziciji razvil močnejše dramatske momente, pa ta vsebuje vrsto liričnih mest - mislimo predvsem na arije, ansamble in zbore -, ki so lahko spodbudila Gerbičevo muzikalno fantazijo. Sicer pa imamo vtis, da je skladatelj snoval svojo opero v prvi vrsti kot muzik in tako je tudi glasbena zasnova dosti tehtnejša od dramske.

Predno preidemo $\mathrm{k}$ oceni in stilni oznaki kompozicije kot celote, si oglejmo muzikalni potek opere in se seznanimo ob tem $z$ njenimi pozitivnimi in negativnimi stranmi.

Opera ima precej obsežno predigro, ki je zgrajena povsem svobodno, fantazijsko. Skoro v celoti se naslanja na motiviko opere, pri čemer je značilno, da je ta, razen $\mathrm{v}$ enem primeru, vzeta iz orkestralnega in ne vokalnega parta, kar že takoj kaže, da je skladatelj vsaj na posameznih mestih opere dal dovolj karakteristično vlogo instrumentalni spremljavi. Čeprav ne bi mogli trditi, da sledi predigra nekemu določenemu progra$\mathrm{mu}$, ni prezreti, da sta $\mathrm{v}$ njej poudarjena dva vsebinska momenta opere: praznovanje Kresa in $\mathrm{s}$ tem $\mathrm{v}$ zvezi ljudsko veselje in razigranost ter tajinstvenost in čarobnost kresne noči. Ker pa je Gerbiču uspelo najti za to in ono dosti živ in prepričljiv muzikalni izraz, učinkuje predigra izvrstno kot razpoloženjski uvod $\mathrm{v}$ opero. Instrumenitacija je mestoma s celotnim izkoriščanjem pihal in trobil polna, vendar ne daje vtisa prenatrpanosti. Skladatelj je tudi znal doseči prav lepe barvne efekte $z$ veščim kombiniranjem in izmenjavanjem posameznih pihal oziroma trobil.

10 Prim. katalog Gerbičevih kompozicij v mapi F. Gerbiča in Jaromile Gerbičeve v NUK, Ljubljana.

11 Cvetko D., ib., 302; Leskovic R., Orkestralna ustvarjalnost skladatelja Frana Gerbiča, dipl. delo, tipkopis, str. 8.

12 Prim. F. Gerbič, Moje življenje v NUK Ljubljana. 
Začetek s prostranimi razložitvami trizvokov tonike in VI. stopnje in močno poudarjeno kadenco na dominanti spominja nekoliko na način orgelskega preludiranja. Sledi podoba kresnega veselja, ki se naslanja na finale 1. dejanja, od koder sta doslovno prevzeta zbor "Glejte tam v daljavi« in njegov živahen orkestralni uvod. Ko intonirajo violine, flavte, oboe in klarineti $\mathrm{v}$ enakomernih osminkah potekajočo in kromatsko pretkano temo v e-molu, zapustimo svet ljudske stvarnosti. To je tema skrivnosti kresne noči in hkrati vodilna tema opere, ki se oglaša še skozi vso opero (prim. 1). Tudi motivika nadaljevanja, ki izhaja iz orkestralne
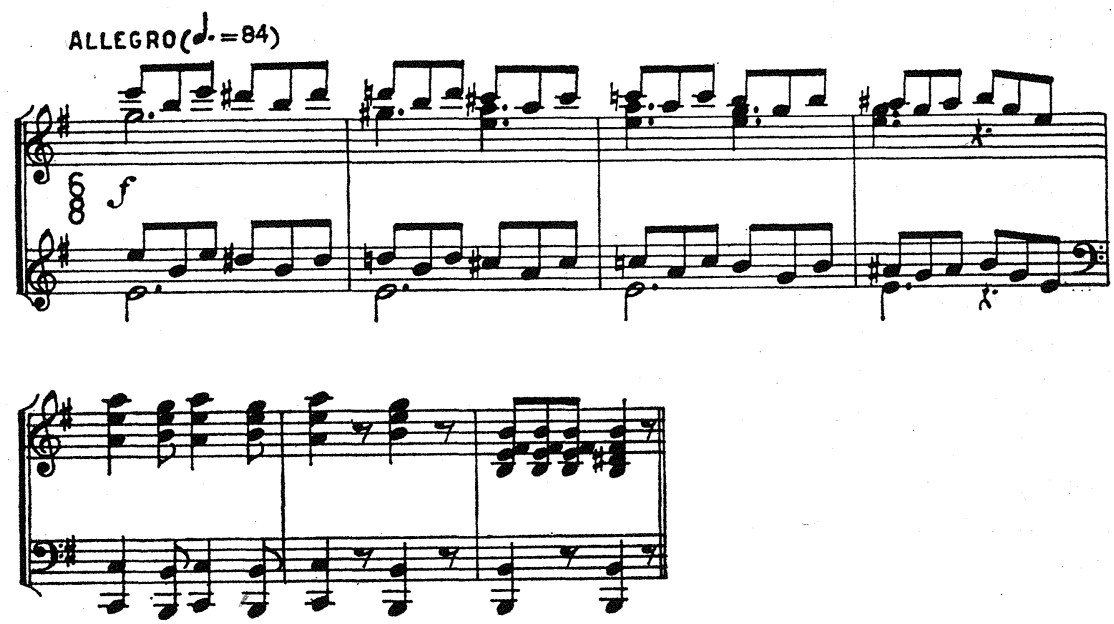

spremljave nastopov Barbe, spada $\mathrm{v}$ bistvu $\mathrm{v}$ isto izrazno območje. Razpoloženje vesele razigranosti zavlada spet, ko se pojavi tema kola z značilnim motivičnim ponavljanjem. Ta tema, ki jo bomo $\mathrm{v}$ spremenjeni obliki še nekajkrat našli $\mathrm{v} 1$. in 2. dejanju, ne zveni specifično južnoslovansko in spominja prej na češko glasbo (prim. 2). V odseku Andante sos-
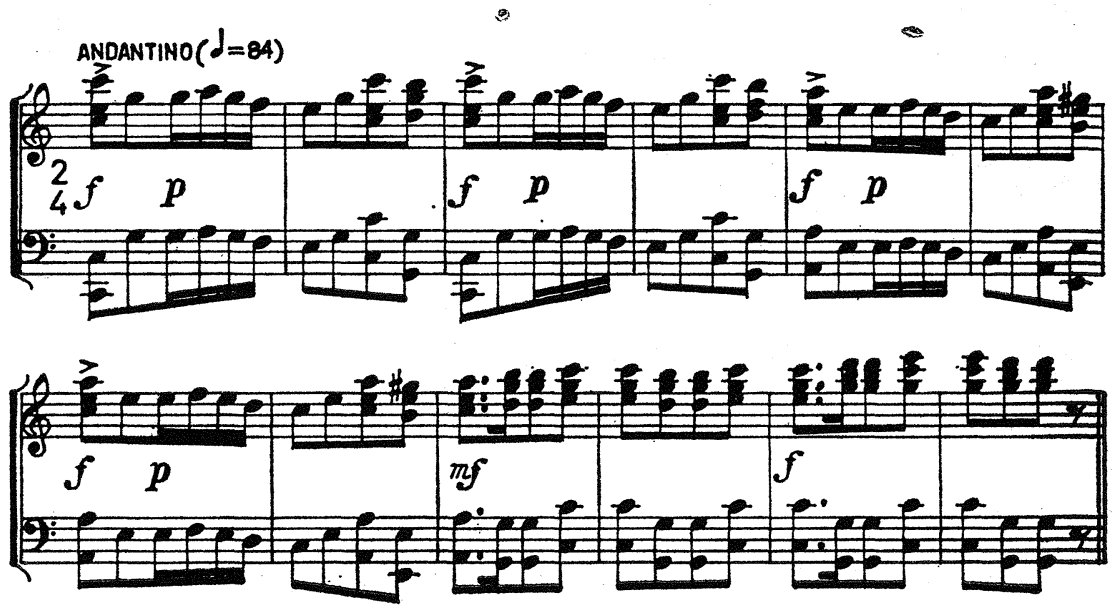
tenuto razvije skladatelj prav privlačno idilično sliko. Tu izvaja nad spremljavo godal oboa ljubke figure, medtem ko prineso rogovi svoj motiv. Sledi ponovitev motivike že omenjenega zbora in kola ter koda s krepkim stopnjevanjem radostnega razpoloženja.

Gradnja prvega dejanja je, če ga gledamo v glavnih obrisih, tridelna in $\mathrm{v}$ nekem smislu simetrična. Medtem ko so na začetku in koncu pretežno razgibani zborovski prizori, je osrednji del, ki obsega arijo, dva dueta in kvartet, izrazito intimnega značaja.

Dejanje začneta dva tematsko zaključena, a po razpoloženju sorodna zbora, ki oznanjata priprave na kres in slavita stare ljudske običaje. Prvega intonirajo triglasno dekleta in se na začetku za hip ujame, bržkone povsem slučajno, s slovensko narodno "Fantič vesel sem rad«.13 Nič manj pristno ljudsko občuten je ritmično živahnejši drugi zbor, v katerem tudi uporaba kromatike $\mathrm{v}$ zvezi $\mathrm{z}$ uvedbo nekaj dvojnih oziroma stranskih dominant ne komplicira izrazne preprostosti. Če se Gerbič tu razločno kaže kot slovenski skladatelj, pa ubira že v kratki medigri, ki povezuje oba zbora, prej nek občeslovanski kot slovenski ton. To in ono je zanj nasploh značilno in se pojavlja še v nadaljevanju opere.

$Z$ nastopom Barbe pride do začasne stemnitve razpoloženja. Začetek njene arije, ki je v da capo obliki, začrta s svojo trpko otožnostjo prav izvrstno lik zapuščene vaške ubožice. Srednji del v E-duru zveni najprej kot priznavanje uživanja ljubezni in mladosti čustveno toplo in neskaljeno svetlo, a prevzame zatem z mislijo o minljivosti mladostnih čarov s̀koro bolesten ton. $\mathrm{Tu}$ nas prevzame zaključni pasus $\mathrm{z}$ ekspresivno melodijo nad ležečo dominantno harmonijo in z nekaj takti resnobno trpke poigre.

Obred posipanja cvetja in praproti, ki je združen $\mathbf{s}$ priprošnjo za blaginjo, okvirja zbor dečkov in deklic, ki sprva spominja melodično na narodno "Mati zakliče pridne dekliče» (prim. 3)..$^{14}$
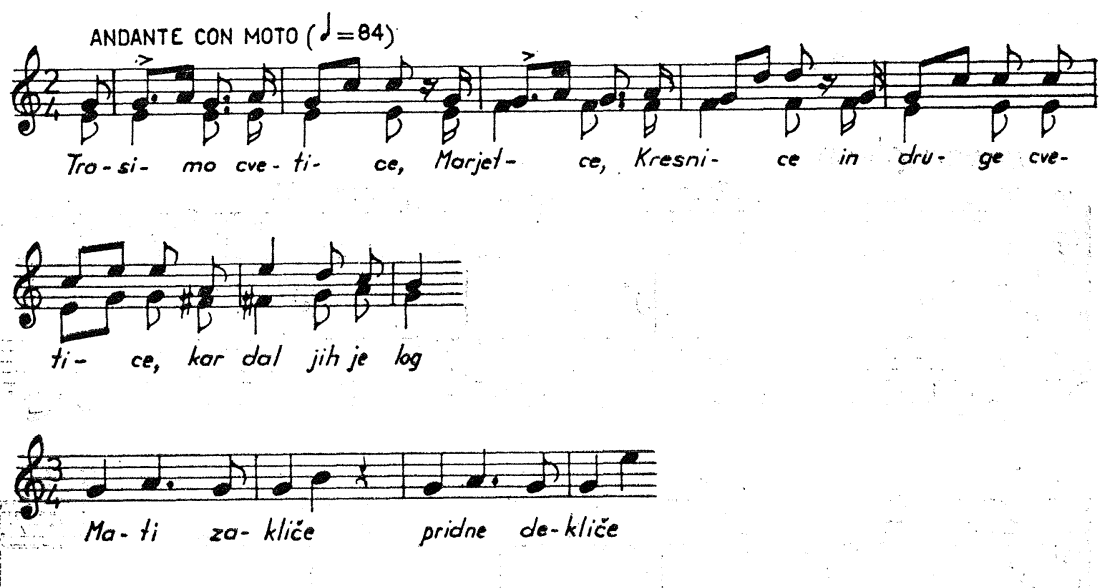

13. Zapis iz okolice Ljutomera hrani Sekcija za glasbeno narodopisje SAZU pod signaturo GNI O 879 .

14 Prim. Žirovnik. J., Narodne pesmi III, Ljubljana 1905/06, št. 6. 
$\mathrm{S}$ tem ljudsko ubranim in otroško naivnim zborom kontrastira iżrazno intenzivna priprošnja, še bolj pa pesem Barbe o čarodejni moči praproti. Le-ta zveni mračno skrivnostno in se izvrstno sklada $z$ značajem besedila. Skladatelj jo je zasnoval iz dveh izrazno sorodnih, a tematsko različnih delov. Prvi obsega periodo dveh šesttaktnih stavkov, kar je vredno omeniti, ker temelji sicer oblikovna gradnja opere pretežno na štiritaktnih in osemtaktnih miselno zaokroženih enotah.

Pripoved Barbe, ki sledi izza melodično prikupnega zbora fantov in deklet, uvajata motiv godal $\mathrm{z}$ značilnim postopom zvečane sekunde $\mathrm{v}$ amolu - ta se ponovi še v e- in h-molu - in daljši recitativ oziroma arioso, v katerem prinese orkester ob besedah: "Tajnosti Šentjanževe noči nadprirodne javljajo močiı vodilni motiv opere. Tu stopnjujejo izraz tajinstvenosti in čarobnosti tudi kratke figure visokih pihal in zmanjšani septakordi. Sama pripoved je zložena $\mathrm{v}$ tonu preproste balade in obsega dve strofí na isto melodijo, ki ju loči kratka medigra $\mathrm{z}$ vodilnim motivom. Kot efektno poživitev občutimo zborovsko repliko na napolitanskem sekstakordu.

Nadaljevanje vse do prihoda Stanka se odvija v izmenjavanju krajših epizod solistov in zbora. Za slednjega je značilno nizanje ponavljajočih se motivov in izraznost, ki je blizu češki romantiki (prim. 4).
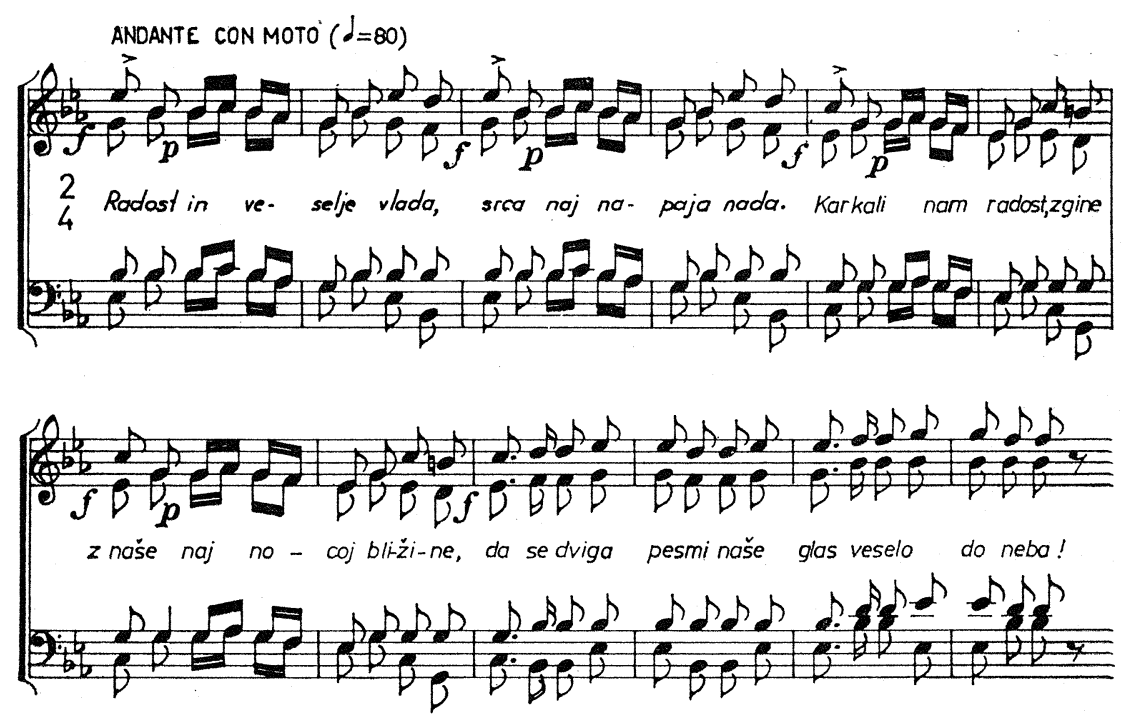

Nastop Stanka markantno uvaja emocionalno impulziven orkestralni stavek s karakterističnim, ob melodičnih in harmonskih spremembah hitro ponavljajočim se motivom (prim. 5). Zdi se kot da tu odmeva klic trobente, ki je nekoč Stanka pozival v vojsko, hkrati pa je čutiti fantovo trenutno duševnio vzburjenje ob spominu na preživele bojne dni. Stankov recitativ, ki ga spremljajo le tu in tam posamezni enostavni akordi in v sredi za nekaj trenutkov prekine orkester $\mathrm{z}$ omenjenim motivom, je navzlic 

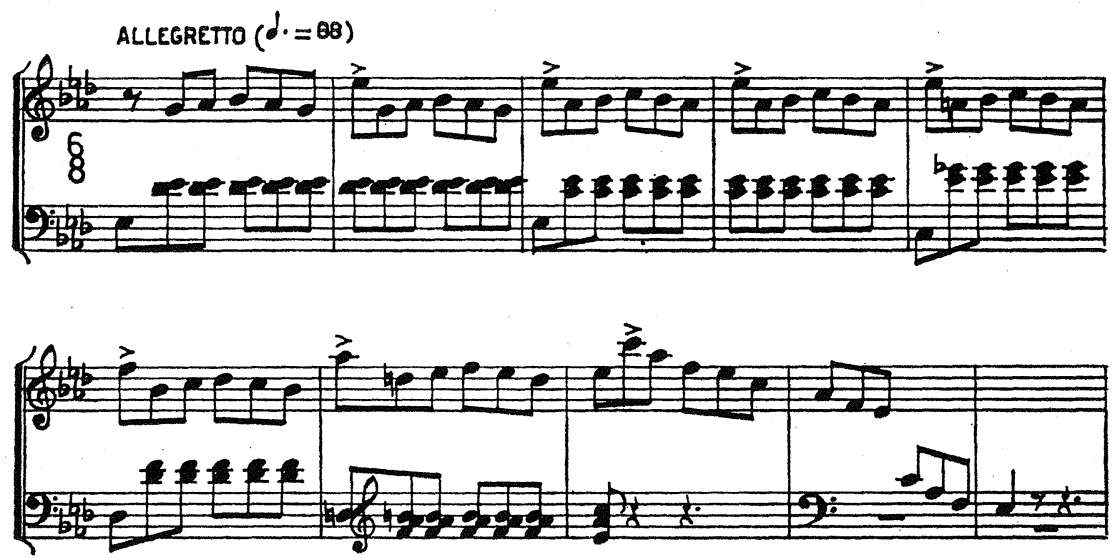

svoji preprostosti dosti izrazit. Orkester pride spet pomenljivo do besede $\mathrm{v}$ širše razpredeni predigri $\mathrm{k}$ sledeči ariji. To medigro čutimo kot podobo junakovega duševnega spokojstva ob vrnitvi domov. Arija je biser Gerbičeve glasbene lirike in izvrstno portretira nežnost in rahločutnost Stanka $\mathrm{v}$ vsej njegovi navezanosti na rodno grudo in drago dekle. Je polna prefinjene, morda nekoliko zastrte čustvenosti, in deluje iskreno in neposredno. Oblikovana je tridelno $\left(\mathrm{ABA}_{1}\right)$, tako da je ob ponovitvi prvi del skrajšan in zvezan $z$ daljšim, izrazno stopnjevanim in pevsko dovolj efektnim zaključkom. Posebej naj opozorimo na samostojnost spremljave v prvem delu, kjer dodajata oboa in flavta $\mathrm{k}$ pevski melodiji fin kontrapunkt.

Moč skladateljevega navdiha se najjasneje razodene $v$ duetu Zorke in Barbe. Prvi del je v e-molu in ga preveva neka slovanska elegičnost, ki je odsev mračnih Zorkinih misli, da ji je ljubi za vselej izgubljen. Drugi del je $\mathrm{v}$ svetlem E-duru in predstavlja $\mathrm{s}$ svojim emocionalnim zanosom ter prevlađujočo optimistično uglašenostjo močan kontrast. Tu pridejo ljubezenska čustva Zorke nezadržano do izraza. Melodija, ki se ponekod razpenja $\mathrm{v}$ širokem loku, je vedno pristno občutena in teče spontano do kraja. Če je bila $v$ prvem delu vseskozi v ospredju Zorka in se je Barba oglašala le s kratkimi replikami, prehaja zdaj vodstvo iz glasu na glas in se oba med seboj tudi lepo prepletata in dopolnjujeta.

Ostali del prizora, v katerem nastopita poleg Zorke in Barbe še Stanko in Cilja, skrita za sceno, učinkuje manj celovito; komponiran je v obliki recitativa, ariosa in ansambla. Medtem ko tu lahko občudujemo zanosno in široko sopransko kantileno Zorke, pa se ne moremo ubraniti vtisa enoličnosti ob njenem recitativu, ki temelji skozi osem taktov melodično in harmonsko na enem samem zmanjšanem septakordu. Kratek kvartet, ki združi vse prisotne $\mathrm{v}$ zlito celoto, je muzikalno dovolj močan, čeravno pogrešamo na začetku, kjer izraža vsak od nastopajočih $\mathrm{z}$ besedami svoje misli in občutja, melodično individualizacijo glasov. Kasneje postane sta- 
vek tudi harmonsko zanimiv, saj se razvije v ozkem območju kar pestra vrsta tonalitet (E-dur, As-dur, h-mol, C-dur, A-dur, E-dur).

Škoda, da je začetek dramskega zapleta začrtan šibko in bledo. Cilja izrazi odločitev, da svoji tekmici Stanka nikdar ne bo prepustila, preveč mimogrede, $\mathrm{v}$ kratkem, dokaj suhem in le s posameznimi akordi spremljanem recitativu. Tudi recitativ Stanka, ki je pripravljen maščevati njeno zlo nakano, ni dosti boljši. Vendar je tokrat orkestralni part zanimivejši, ker prinaša značilni motiv, ki smo ga že spoznali ob prvem nastopu.

Kot lahkoten in zabaven intermezzo občutimo duet Janeza in Cilje, $\mathrm{v}$ katerem se maice okoren kmečki fant poteguje za pretkano vdovo, ki ga porogljivo zavrača. Če morda izvzamemo le tu in tam kakšno bolj pusto mesto, moramo ugotoviti, da je ta duet muzikalno dovolj svež. V začetnem delu je mestoma vloga orkestra, ki prinaša ob pevski melodiji plesno razigrano motiviko (med drugim motiv kola), precej samostojna. Zlasti $\mathrm{v}$ tekoče parlandiranem zadnjem delu s tipičnimi buffo efekti, je pokazal skladatelj tudi smisel za glasbeni humor.

Finale ne kaže zahtevnejše ansambelske zasnove. Nastopi solistov so redki, pretežno epizodne narave in ne predstavljajo izrazitejšega kontrasta nasproti zboru. Razen tega pogrešamo prave organične rasti in gradacije, zaradi česar finale ne napravi močnejšega vtisa in učinkuje komaj več kot venček zborovskih pesmi. Te so sicer, vzete posamezno, privlačne, vendar združene $\mathrm{v}$ celoto ne morejo zadovoljiti kot zaključek dejanja.

Finale je zamišljen kot razpoloženjska slika kresnega večera. Uvaja ga poskočna plesna pesem, ki tokrat prinaša temo kola; ta je že nekajkrat nastopila $\mathrm{v}$ orkestru od predigre dalje, tudi v zborovski verziji. Osrednji del finala tvori meditativno ubrana Ave Maria, ki izzveni v preprosto, a subtilno poigro. Tej sledi neposredno $\mathrm{v}$ fortissimu živahno razposajen orkestralni uvod $\mathrm{v}$ zadnji del, ki je radostno stopnjevana pesem ob pogledu na plamtenje kresov na bližnjih vzpetinah. Tu zasluži pozornost zbor "Glejte tam v daljavi«, ki učinkuje s svojim krepkim ritmom (triole, osminke, punktiranje). Žal pa je poznejši pasus «Pradedje naši $v$ davnih dneh" s svojim motivičnim ponavljanjem nezanimiv in dolgočasen. Boljši je sklep, kjer je doseženo stopnjevanje $s$ hitrejšim gibanjem (šestnajstin$\mathrm{ke}$ ) in tu in tam $\mathrm{z}$ uporabo stranskih dominant.

Drugo dejanje večinoma nadaljuje s slavjem kresne noči veselo razpoloženje in tako, če izvzamemo dramatsko vzburjeni in resnobni zaključek, ne predstavlja izrazitega kontrasta $\mathrm{k}$ prejšnjemu dejanju. Začne ga ritmično krepak zbor fantov $\mathrm{v}$ tridelni obliki $\left(\mathrm{abaa}_{1}\right)$, ki je poln razigrane radosti in spada zaradi svojega živega izraza in sveže melodične inspiracije med najboljše $\mathrm{v}$ operi (prim. 6).

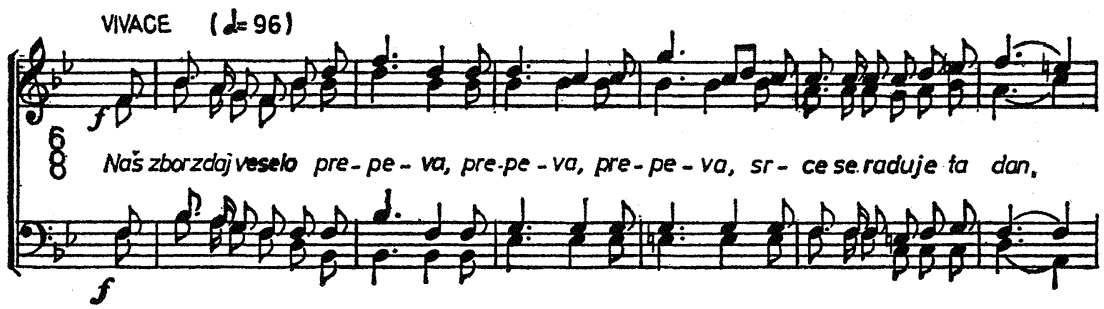


Kot se res lahko navdušujemo nad tem zborom, pa nas kmalu razočara Gerbičev način glasbenega ilustriranja. Pasus, v katerem godala in pihala ponazorujejo s hitro ponavljajočimi se figurami in pasažami hitenje deklet na vrh hriba, deluje namreč dokaj naivno in daje prej vtis tehnične etude kot glasbene slike.

Dosti bolje se izkaže Gerbič kot glasbeni ilustrator v liričnem prizoru Petra, kjer zasluži $\mathrm{v}$ uvodnem recitativu pohvalo prepričljiva zgovornost orkestra. Tako valovanje vode oziroma žitnega polja lepo slikajo triolne figure godal, ki jih dopolnjujejo pihala, medtem ko kaže nemirna spremljevalna figura ob besedah: "Srce radostno moje bije», da je znal skladatelj tankočutno prisluhniti tudi detajlom besedila.

Arija Petra $\mathrm{v}$ tridelni obliki $\mathrm{s}$ skrajšanim da capo razodeva dosti plemenite melodike in izzveni kot vzvišena himna domovini. Tu sta po svoji melodični substanci in izrazitosti krajna dela bolj enovita in strnjena kot pa srednji, kjer so zaznavni kar trije kontrastni odseki. Prvega označuje preprosta, široko spevna in čustveno iskrena melodija, katero obvladuje punktirani ritem in podpirajo skoro le akordi tonike in dominante. Drugi odsek je zanimiv zaradi ilustrativnega značaja spremljave, ki prinaša motiviko kola iz prejšnjega dejanja, medtem ko govori besedilo o plesu okrog kresa. $V$ tretjem so dosežena dovolj močna izrazna stopnjevanja $\mathrm{s}$ pomočjo sekvenciranja $\mathrm{v}$ melodiji in $\mathrm{z}$ alternacijami $\mathrm{v}$ harmoniji.

$\mathrm{Ob}$ neposredni bližini te arije občutimo nekatera sledeča mesta še toliko bolj pusta in neizrazna. Tako je zbor fantov in deklet, ki so se vrnili iz goščave s suhladjo, dokaj neinventiven. Še bolj velja to za nastop Janeza. $\mathrm{s}$ hitrim parlandiranjem ter neokusnim ponavljanjem besedi. Drugače je z Janezovo dvodelno pesmijo, ki s svojim odločnim ritmom in nekaterimi širokimi intervalskimi postopi prav uspešno očrta lik kovača. Ponavljajoče se figure zmanjšanih kvint $\mathrm{v}$ čelu, kontrabasu in fagotu oziroma zmanjšanih septakordov $\mathrm{v}$ flavtah in piccolu nad harmonsko podlago godal, ki nakazujejo vzplamtenje ognja, so same po sebi dokaj konvencionalne, vendar spričo omenjene instrumentacije niso brez zvočne efektnosti.

Kvintet, ki ga intonirajo Zorka, Cilja, Matija, Peter in Janez, potem ko je zbor ob žaru ognja $v$ kratkem stavku izrazil svoje radostno vzburjenje, je seveda, če ga gledamo $z$ dramskega vidika, odveč. Samo besedilo je nepomembno in komaj bledo nakazuje spomin in slavljenje preteklosti prednikov. Zato je še toliko bolj vredno občudovanja, da je Gerbiču uspeīo ustvariti na tako besedilo muzikalno lep in izrazno globok ansambel. Ker imajo vsi solisti isto besedilo in izražajo isto občutje, je razumljivo, da je gradnja kvinteta $\mathrm{v}$ osnovi homofonska. Kljub temu pa ne manjka razgibanosti glasov in mestoma polifonske poživitve. Glasovi so uporabljeni smotrno in ekonomično. Celotno muzikalno dogajanje se odvija dovolj kontinuirano in tudi izrazna gradacija proti koncu je krepka in prepričljiva.

Kvintetu slede spet nekatera šibkejša mesta, tako solo Zorke v obliki male dvodelne pesmi, osemtaktna kantilena Petra ob akordični podpori zbora in kratka zöružitev solističnega ansambla z zborom. Ker daje slavje kresne noči že tako vtis razvlečenosti, pa so omenjeni pasusi kakor tudi 
ponovitev kvinteta $\mathrm{v}$ zborovski zasedbi povsem odveč. Seveda to ne velja za ples, ki vnaša scensko razigranost in se zdi pri slavju skoro nepogrešljiv. Za ples je sikladatelj poskrbel $\mathrm{z}$ dovolj temperamentnim in pestrim kolom. Uvaja ga sekvenčno se ponavljajoči motiv godbe kot poziv na ples, ki nas spominja nekoliko na polko iz Smetanove "Prodane neveste" (prim. 7). Sledeči zbor, ki opeva radosti in čare kresne noči, uspešno podpira

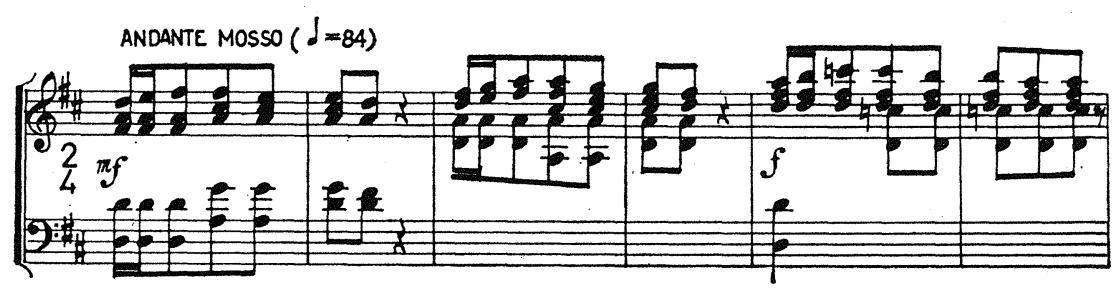

vzdušje razigranosti in ga lahko uvrščamo med pomembnejše zborske točke opere. Skladatelj ga je zasnoval $\mathrm{v}$ treh kontrastnih delih (abc) in dosegel oblikovno zaokroženost $\mathrm{s}$ ponovitvijo $\mathrm{b}$ in a na koncu. Razen tega je pokazal tudi precej smisla za muzikalno ilustracijo besedila. Ko to govori o plesu, se pojavi v basih sta ritmična figura kot na začetku kola. Ježa in vrišč čarovnic sta naznačena $\mathrm{s}$ šestnajstinskimi figurami v sopranu in altu oziroma basu ter harmonsko alteracijo. Po celotni ponovitvi kola, ki je izvedena le z majhnimi spremembami, vodi nekaj taktov orkestralne medigre $\mathrm{v}$ kratek recitativ in napitnico Petra, ki podobno kot prejšnji zbor posrečeno dviga razpoloženje. Skladatelj jo je vlil v malo tridelno pesemsko obliko abc $\mathrm{z}$ zborovsko ponovitvijo zadnjega dela. Vsakega od njenih delov karakterizira markanten ritem, s katerim se dobro ujema tudi preprosta, deklamativna in vseskozi strogo silabična melodija. Naj še ne pozabimo omeniti kromatske pasaže flavte $s$ trilcem na začetku, ki ilustrira natakanje vina. Celotna napitnica se z izjemo drugega dela, ki je na novo komponiran, doslovno ponovi. Ta ponovitev kakor še sledeča druga ponovitev plesa pa sta spet odveč in samo stopnjujeta razvlečenost. Za plesom zadoni $\mathrm{v}$ klenem zborovskem stavku še ganljiva pesem "Nekaj mi srce teži», ki kaže v začetku naslonitev na narodno $" T$, te, te dobro poznam».15 že dramaturško ponesrečeni prizor družabne igre golobnjak večinoma tudi muzikalno ne napravi ugodnega vtisa, saj so tako zborovske kot solistične partije preveč enostavne in nedomiselne.

Slavje kresne noči ima izrazito kantatni značaj. Dramatski moment nastopi šele, ko se razvname med Zorko in Ciljo prepir in tako med obema zaostri konflikt. Ker pa je Gerbič uvedel in izpeljal ta moment nespretno v libretu, ne preseneča, da se mu zadnji del drugega dejanja tudi kompozicijsko ni povsem posrečil in da ta ni dovolj strnjen in kontinuiran.

Postopek $\mathrm{s}$ sekvenčno ponavljajočim se motivom $\mathrm{v}$ violončelih, ki naj bi bil odraz naraščajoče napetosti pričakovanja navzočih spričo Zorki-

15 Zapis te narodne pesmi hrani pod signaturo GNI O 11.288 sekcija za glasbeno narodopisje SAZU. 
nega aludiranja na Ciljo, je naiven in brez prave dramske moči. Izpovednost orkestra je izrazitejša na nekoliko poznejšem mestu, kjer prinese klarinet ob spremljavi godal značilen triolni motiv v g-molu, ki se ponovi $\mathrm{v}$ B-duru in nato nadaljuje $\mathrm{v}$ ostinatnih frazah nizkih godal in fagotov.

Vredno je omeniti, da je znal Gerbič tu spretno uporabiti reminiscentno motiviko. Z njo je hotel, ko Zorka recitira klevetniško pismo Cilje, poudariti resničnost dejstev nasproti lažnim trditvam. Za neresnično navedbo, da se je Zorka svojemu dragemu izneverila, se pojavi $\mathrm{v}$ orkestru motiv njenega speva iz 1. dejanja, $\mathrm{v}$ katerem je izpovedovala svojo ljubezen do Stanka (prim. 8). Podobno komentira orkester krivično obdol-

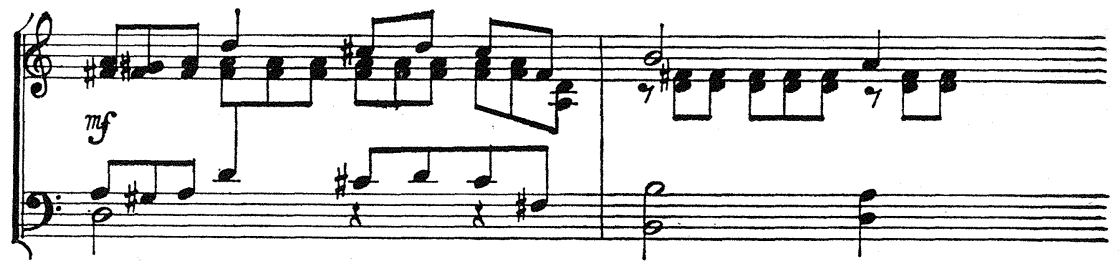

žitev, da se Zorka zabava z drugimi fanti, z motivom, ki je vzet iz zbora iz 1. dejanja, kjer fantje in dekleta sprašujejo Zorko, ki je v skrbeh za Stanka, zakaj je žalostna in zamišljena (prim. 9). Nastop zbora je v obrav-
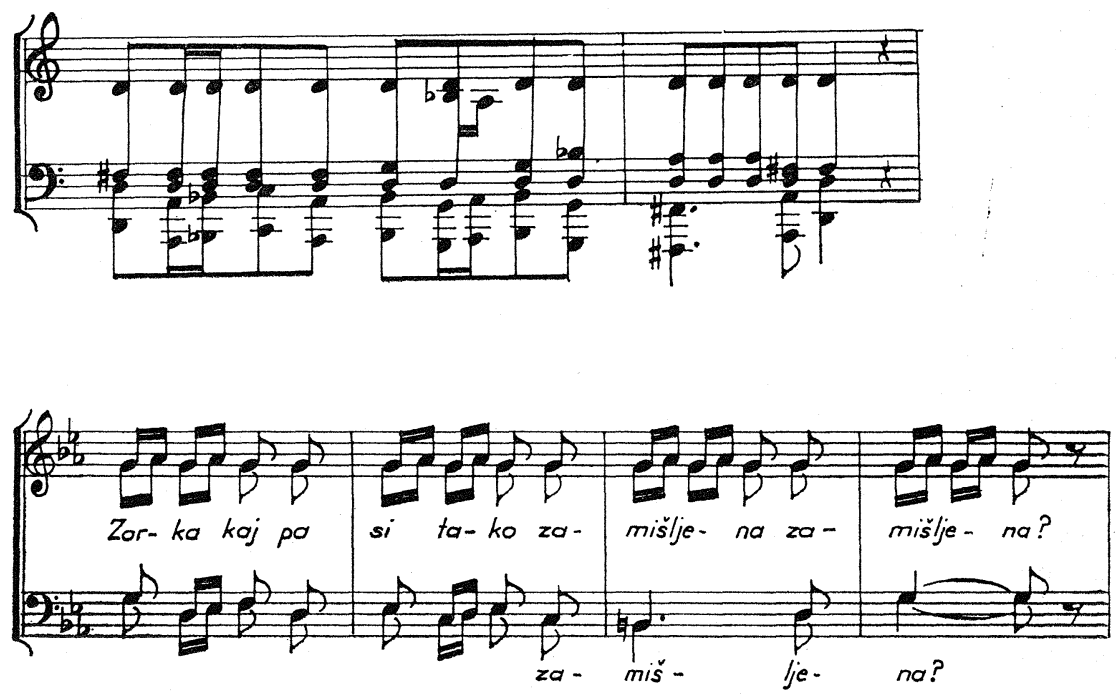

navani sceni precej neizrazen. Ko graja zlobno dejanje, poje nekam neprizadeto, namesto da bi izražal ostro ogorčenje.

Nedvomno pa se je Gerbič visoko povzpel v obsežnem duetu Zorke in Cilje, kjer je razsipno izpel svoje morda najlepše glasbene misli, za katere se zdi, da kar nenehno vro iz njegove fantazije. Razen tega je tu z znatnim smislom za njuno profiliranje dovolj jasno postavil obe tekmici drugo 
nasproti drugi. Duet uvaja dvodelni spev Zorke, $v$ katerem ta izpoveduje svoja čustva do Stanka. Prvi del je v C-duru in se začenja s čustveno nežno in kantabilno melodijo, katere ekspresivnost mestoma stopnjuje uporaba alteracije oziroma zadržka. Drugi del, ki je $\mathrm{v}$ As-duru in nakazuje obliko $\mathrm{aba}_{1}$, spominja $\mathrm{v}$ melodični konturi in ritmu rahlo na spev Zorke $\mathrm{v}$ prizoru $\mathrm{z}$ Barbo iz 1. dejanja. Čeprav ostane ritem $\mathrm{v}$ naslednjem odseku pravzaprav nespremenjen, je nastop brezobzirine Cilje adekvatno začrtan $\mathrm{s}$ spremembo tonalitete (trši $\mathrm{F}$-dur) in pospešenjem tempa. Nedvomno nas najbolj očara zaključni del v Des-duru, ki je po svojem splošnem občutju bliže italijanski kot slovanski operi. Izrazne gradacije, ki jih je tu skladatelj izvedel, so krepke in vodijo $\mathrm{k}$ efektnemu in prepričljivemu višku. Zaključni del se začenja s čustveno intenzivno in široko melodijo Zorke, ki ponovno poudarja svojo ljubezen. Kratek in odločen ugovor Cilje, ki se ni pripravljena umakniti, je muzikalno markanten in izstopi dovolj močno $\mathrm{z}$ nenadnim nastopom harmonskega F-dura nasproti dosedanjemu Des-duru. Sledi ponovitev začetne melodije obravnavanega odseka, ki jo tokrat prinese Cilja in vokalno blesteča združitev obeh glasov, pri čemer prehaja vodstvo zdaj na to zdaj na ono protagonistiko.

Resnobnost situacije odmeva tudi $\mathrm{v}$ trpkem in harmonsko nemirnem zboru "Konec je radosti», ki postopno modulira $\mathrm{v}$ kvintnem krogu navzdol vse od Cis - do D-dura in se zatem za nekaj časa ustali v e-molu, nakar se doživetje obžalovanja vrednega dogodka zgosti v lepem razpoloženjskem ansamblu "Sloga luč nebeška, pošlji ti tvoj žarı. Intonirajo ga Zorka, Meta, Matija, Peter in Janez, pozneje pa se vanj s svojimi replikami vključi še Cilja. Če izvzamemo začetek $\mathrm{s}$ široko razpeto in ekspresivno melodijo Zorke in zaključni del $\mathrm{z}$ nekoliko bolj izrazitim vodenjem glasov, je moč tega ansambla prej $\mathrm{v}$ harmoniji $-\mathrm{v}$ tej zvezi je opoozriti na smiselno uporabo septakordov in alteracij - kot pa $\mathrm{v}$ melodiji.

Po hibah, ki so se pokazale v partiturti ob nespretni uvedbi dramskega momenta, se zdi, da steče zaključek dejanja kar presenetljivo dobro. Skupnost fantov in deklet, $\mathrm{ki}$ sedaj poseže $\mathrm{v}$ dejanje, se zavzame za Zorko ter obsodi Ciljo, je začrtal skladatelj s precej krepkimi potezami. Razen tega je važno, da intenziteta muzikalnega dogajanja ne opeša in vzdrži vse do kraja.

Tretje dejanje se po prevladujočem mračnem in skrivnostnem izrazu močno razlikuje od prvih dveh. Njegova zasnova je $\mathrm{v}$ bistvu dvodelna: obsežen lirski uvod in višek dramskega konflikta $\mathrm{z}$ razpletom. Turobno in zgrozljivo vzdušje je pričarano že takoj na začetku daljše orkestralne

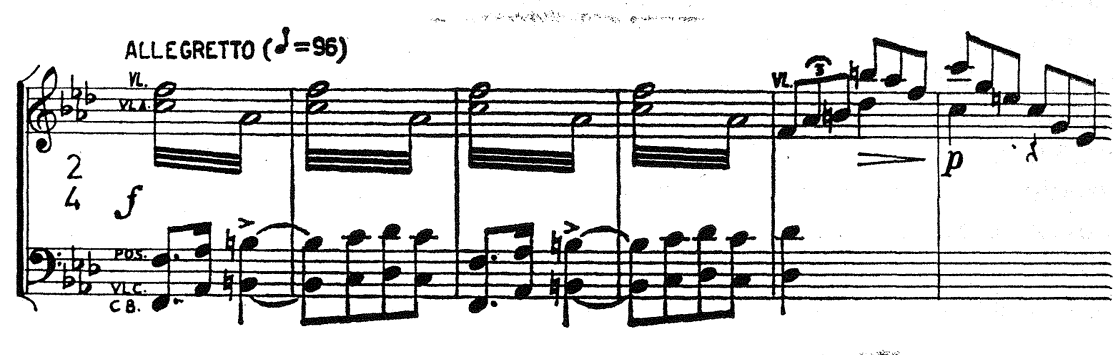


predigre, kjert intonirajo pozavne $\mathrm{v}$ unisonu $\mathrm{z}$ violončeli in kontrabasi ob tremolu violin in viol temo, ki jo karakterizirajo postop zvečane se kunde, punktiran ritem in sinkopa (prim. 10). Ta tema je identična s kasnejšim vznemirljivim Stankovim klicem na pomoč in daje kompoziciji svojstven ton. Pojavi se najprtej v f-molu, pozneje pa še v b- oziroma es. molu in $\mathrm{v}$ znatni meri obvladuje prvi del. Turobno vzdušje podčrtuje razen omenjene teme in instrumentacije tudi sorazmerno pogosta uicraba zmanjšanih septakordov. Drugi del, ki je v d-molu in hitrem tempu, predstavlja kontrast. Čeprav smo še vedno v območju nadnaravıe جa, je občutek groze prešel. Nahajamo se $\mathrm{v}$ pravljičnem, vilinskem svetu, kaierega je znal skladatelj upodobiti nič manj živo. Kartakterističen intervalsiki postop zmanjšane kvinte (f 1-h oziroma d 1-gis) na začetku predstavlja klic rusalk. Siedi živahen ples pravljičnih bitij, ki je s svojo kratko ponavljajočo se motiviko izrazito slovanskega značaja.

Z vzdušjem zaključka predigre se izvrstno ujema dvoglasni zbor kresnic in rusalk, ki je zasnovan $v$ zloženi pesemski obliki $A B$, pri čemer je vsak od obeh obsežnejših delov formalno zaokrožen (aba). Drugi del prinaša med drugim sicer preprosto, toda lepo in spevno melodijo, ki jo poje zbor unisono $\mathrm{z}$ orkestrom. Pesem preide neposredno $\mathrm{v}$ ples. Ta je identičen $\mathbf{s}$ tistim $\mathrm{v}$ predigri, le da je tokrat na koncu razširjen $\mathrm{s}$ kodo.

Ko rusalke in kresnice izginejo in se pojavi na usodnem kraju Stanko, naznani vso resnobnost trenutka motiv, ki zazveni $\mathrm{v}$ mračni globini violončelov, kontrabasov in fagotov (prim. 11). Daljši ariozo Stanka teče v

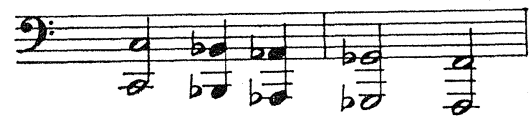

ekspresivnih melodičnih linijah in je odraz junakovega željnega pričakovanja kakor tudi gneva do maščevalne krčmarice. Njegovo tonalno območje je razmeroma širtoko, hkrati pa ne manjka nekaj nenadnih modulacijskih prehodov. Sledeča arija Stanka je v prvem delu, ki je v As-duru, zamišljena kot himna ljubezni. Pomen besedi je vsesplošen in zato zveni tudi glasba nekako nadosebno in vzvišeno. Ker je osrednji del v Es-duru izraz Stankove osebne ljubezni do Zorke in njegovega doživljanja ljubezenske blaženosti, je ta bolj čustveno razgiban in neposreden. Oblikovno zaključenost arije je skladatelj dosegel tako, da je na koncu ponovil z novim besedilom začetni stavek, na katerega navezuje potem še po štiri takte vokalnega in orkestralnega sklepa.

$\mathrm{Ob}$ nastopu Zorke prinese orkester $\mathrm{v}$ d-molu vodilni motiv opere. Podobno kot Stanku dá skladatelj tudi Zorki neposredno pred grozečo katastrofo izpeti svoja duševna doživetja. Tako ji je dodelil široko zasnovano solistično sceno, ki se začenja in zaključuje $\mathrm{z}$ molitvijo, medtem ko je $\mathrm{v}$ sredini obsežna arija. Vsak od teh delov je celota zase, med seboj pa jih povezuje recitativ. Molitev je mala tridelna pesem (abc), preprosta, kristalno čista in zelo zadržana. Zveni predvsem kot vdana in ponižna prošnja in je daleč odmaknjena izrazu srčnega nemira in vročih želja. Arija 
je edini primer svobodno prekomponirane arije $\mathrm{v}$ operi in se sestoji iz več po tonskem načinu in izrazu bolj ali manj kontrastnih odsekov, katerim sledi vsakikrat še krajša orkestralna poigra. Formalna zasnova je $a b c d \in f$. Prvi del $v$ D-duru izraža srečo in radost, ki ju Zorka doživlja v ljubezni do Stanka. Zato razgibane oktavne pasaže na začetku, ki pa so nekoliko konvencionalne. Ko se pojavi $\mathrm{v}$ drugem delu dvom o Stankovi vrnitvi, modulira spev v G-dur in e-mol in šele $\mathrm{v}$ poigri pride do vrnitve v izhodiščni D-dur. Ob vprašanju: "SSe li povrne še nazaj? Kaj videla ga bom še kdaj?» je poudarjena bol z uporabo disonance in septakordov na VII. in II. stopnji. Tretji del je vsaj na začetku, kjer Zorka obudi spomin na blažene trenutke s Stankom, izrazno blizu prvemu, medtem ko nastopijo v nadaljevanju tudi rahlejše stemnitve. Naslednji, najdaljši odsek, ki je pretežno v h-molu, je izraz hrepenenja za ljubim. Potem ko se je tu melodija sprva že lepo in dosti obetajoče razvila, pa se v nadaljevanju, če izvzamemo morda zadnja dva stavka, skoro ne moremo ubraniti vtisa enoličnosti. Razen tega bi bilo ponekod želeti tudi več čustvene intenzitete. Najbolj svež in neposreden se zdi melodični navdih $\mathrm{v}$ nežnem petem delu v G-duru. Zaključek navezuje deloma na misli tretjega odseka, deloma pa prinaša novo gradivo in doseže učinkovito gradacijo in višek.

$\mathrm{V}$ nadaljevanju se opera odvija $\mathrm{v}$ ostrih izraznih kontrastih. Ko stopi Zorka na most, da bi $\mathrm{v}$ vodi zazrla podobo usojenega ženina, poje preprosto in skoro vedro ubrano melodijo, ki niti malo ne dá slutiti napetega in nemirnega pričakovanja odločilnega trenutka (prim. 12). Končni kon-

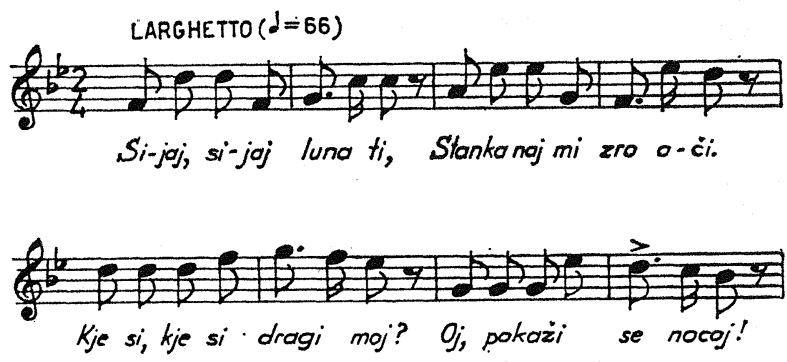

flikt Zorke in Cilje in dramski vrh je skladatelj zasnoval le v skopih potezah. Glasbeno slikanje spopada nasprotnic na mostu in njunega padca $\mathrm{v}$ vodo ne impresira. $\mathrm{V}$ celoti temelji na nekaj zmanjšanih akordih tremola godal, ki jih tu in tam podvajajo pihala oziroma trobila. Takoj zatem prepeva, nič hudega sluteč, zbor fantov in deklet, ki se vračajo s kresovanja, vesel napev. Tako nas toliko bolj prevzamejo Stankovi klici na pomoč, ki jih poznamo že iz orkestralne predigre. Tudi kratko reagiranje ob dogodku presenečenega in prestrašenega zbora je precej prepričljivo. Skladatelj ga vodi ritmično krepko $\mathrm{v}$ unisonu ali ponekod $\mathrm{v}$ štiriglasju z zmanjšanimi septakordi. Krajša orkestralna medigra $\mathrm{z}$ značilnim motivom klica na začetku izraža splošno vznemirjenje, ki še vlada, medtem ko nekateri iščejo $\mathrm{v}$ reki izginulo krčmarico in vodi Stanko Zorko iz čolna na breg. 
Ko nastopi pomirjenje, sledi nekaj lepih strani nežnega in neskaljeneģa lirizma, ki jih je Gerbič dodelil Stanku/in Zorki in zasnoval v štirih krajših delih. Začenja Stanko s preprosto deklamativno, a iskreno občuteno melodijo. Njegov spev se širše razpne šele v drugem delu, kjer doživi tudi izrazno stopnjevanje. Zorka, ki se je pravkar prebudila iz nezavesti, poje $\mathrm{v}$ kratkih, prekinjenih recitativnih frazah, ki jih dopolnjuje orkester $\mathrm{z}$ ekspresivno motiviko. Četrti del je ponovitev drugega in ga uvaja ob tremolu godal Zorka, nakar se oba junaka, zdaj dokončno združena $v$ ljubezenski sreči, izpojeta $\mathrm{v}$ dvospevu, v katerem vodi Zorka.

$\mathrm{V}$ sledeči pripovedi Stanka vzbudi pozornost uporaba reminiscentne motivike. Ko Stanko omenja svojo vrnitev domov, prinese orkester $\mathrm{v}$ nekoliko spremenjeni obliki značilni motiv, ki je v operi uvedel prvi njegov nastop. Podobno spremljajo besede "Ko si iznad mostu me zvala" violine z začetno melodijo iz speva, ki ga je Zorka pela na mostu. Ne smemo prezreti, da je ob kratkem poročilu o spopadu med Zorko in krčmarico vzplamtelo $\mathrm{v}$ skladatelju za nekaj trenutkov kar precej dramatske sile. $\mathrm{V}$ tej zvezi naj opozorimo na orkestralni motiv, ki z ostrim ritmom (triole, punktiranje) in disonanco dobro asociira borbo, kakor tudi $\mathrm{v}$ nadaljevanju na nenaden prehod iz c-mola čez napolitanski sekstakord v Desoziroma Ges-dur.

Zaključek opere je manj zadovoljiv. Nastop zbora z nekaj takti hvalospeva ob srečnem izidu in zmagi dobrega nad zlom že spričo svoje kratkosti ne more močneje učinkovati kot himnitična apoteoza, kakršno najdemo $\mathrm{v}$ nekaterih romantičnih operah. Ko sicer zatem opera izzveni zvočno efektno $z$ durovo varianto vodilnega motiva, $\mathrm{ki} \mathrm{mu}$ je dodan širok plagalen sklep, se vprašujemo, ali je njegova uporaba na tem mestu povsem smiselna, saj gre za motiv skrivnosti kresne noči, medtem ko ni srečni konec pravzaprav nič drugega kot rezultat hrabnega posega Stanka v dogajanje.

Iz gornje obravnave opere je razvidno, da "Kres», če ga vrednotimo iz strogo umetniškega aspekta, ni zaokrožena in celovita glasbeno scenska stvaritev. Njena osnovna hiba je slab libreto, iz česar v znatni meri izhaja neizenačenost kvalitete kompozicije. Ne glede na to pa moramo ugotoviti, da je skladateljeva invencija večinoma prerasla neizraznost besedila in da je marsikatera stran partiture dovolj inspirirana in lepa. Tako se lahko vsaj v glavnem strinjamo s Kuhačevo sicer zelo pavšalno in ne dovolj kritično izjavo: "Deine Oper ist sehr schön, manche Stellen sind geradezu entzückend; die Arbeit vorzüglich ...16 Med uspešne dele partiture lahko uvrstimo solistične speve, ansamble in vrsto zborov, kar kaže skladateljev nagib do liričnega in razpoloženjskega. Najvrednejša mesta so nekatere arije in dueti, predvsem ariji Stanka iz prvega in zadnjega dejanja ali arija Petra iz drugega dejanja ter dueta Zorke in Barbe iz prvega ter Zorke in Cilje iz drugega dejanja. Zlasti $v$ slednjih dveh sta melodična invencija in izraznost tako močni, da se ne zdi preveč tvegana trditev, da tu Gerbič ne zaostaja za nekaterimi svojimi pomembnimi sodobniki v svetiu. Poduariti je treba, da je znal avtor ravno $\mathrm{v}$ arijah in duetih plastično začrtati

16 Prim. Kuhačeva korespondenca, Arhiv Hrvatske, knj. XI, št. 182, 9. III. 1898. 
like nastopajočih oseb, ki so $\mathrm{v}$ glasbi mnogo bolj zaznavni kot $\mathrm{v}$ pesniško pomanjkljivem besedilu. Omenjenim točkam so po vrednosti še precej blizu kvintet in sekstet iz drugega dejanja, zbor fantov iz začetka drugega dejanja, o katerem je $\mathrm{v}$ zvezi $\mathrm{z}$ njegovo vključitvijo $\mathrm{v}$ spored koncerta zagrebškega društva "Kolo» pravilno sodil Kuhač, da bo dobra reklama za opero ${ }^{17}$ ter zbori "Radost in veselje» in "Glejte tam v daljavi» iz prvega in "Čuda se nocoj godijo" iz drugega dejanja.

Za arijami in ansambli zaostajajo recitativi oziroma ariozi, kjer se spričo neizraznosti pevskega parta in orkestralne spremljave, ki se omejuje le na nekaj bolj ali manj ponavljajočih se akordov oziroma figur, včasih ne moremo ubraniti vtisa enoličnosti in stereotipnosti. $V$ tej zvezi je zlasti usodno, da je manjkalo skladatelju moči pri snovanju dramatsko odločilnih mest, za kar je v prvi vrsti iskati vzrok $\mathrm{v}$ medlosti libreta. To pa seveda ne pomeni, da bi ne bilo izrazno prepričljivih in muzikalno lepih arioznih pasusov, kjer se tudi znatno razširi skladateljeva harmonska paleta $\mathrm{s}$ prehajanjem $\mathrm{v}$ oddaljenejše tonalitete.

Čeprav je Gerbičevo načelo opernega oblikovanja primat človeškega glasu, pa tu kakor še na nekaterih drugih mestih opere ne gre prezreti pomembnosti orkestralne spremljave, ki učinkovito dopolnjuje glas in pove tisto, kar ni več $\mathrm{v}$ moči besedi. Na pomembnost orkestra vobče kažejo posamezni instrumentalni uvodi, medigre in poigre, včasih kar dosti samostojno koncipirana spremljava in ne nazadnje uporaba pomenskega motiva in reminiscentne motivike. Slednje je tudi jasen dokaz za Gerbičevo prizadevanje, da svojo kompozicijo psihološko intenzivira in poglobi. Seveda ne smemo v tej zvezi pozabiti na obsežno predigro, ki lahko zavzema spričo zvočne efektnosti in celovitosti $\mathrm{v}$ tedanji še zelo skromni slovenski instrumentalni tvornosti vredno mesto. Sicer pa je orkestracija skozi vso opero izvrstna in kaže tudi skladateljevo težnjo, da s primernim izborom instrumentov podčrta vsebinski moment dogajanja.

Do uporabe pomenskega motiva je privedla Gerbiča predvsem želja, da muzikalno jasno odrazi značilni vsebinski komponenti drame - čarobnost in tajinstvenost kresne noči. Vendar se Gerbič ni naslonil na princip simfoničnega razvijanja in spreminjanja, ki je značilen za novo romantično smer. Vodilni motiv ostane pri njem navzlic spremembam tonalitete $\mathrm{v}$ bistvu nedotaknjen. Ne glede na to je takšen enostavnejši in starejši način uporabe pomenskega motiva dovolj zanimiv, ker kaže na določen koncept opere kot izrazne oblike in je skladatelju omogočil tesnejšo idejno in oblikovno povezavo delov $\mathrm{v}$ celoto. To se zdi toliko bolj važno, ker Gerbič kljub temu, da je opustil delitev partiture na formalno zaključene številke, sicer še ni dosegel večje muzikalne kontinuitete. Posamezne arije, ansambli in zbori se zaključujejo z jasno poudarjenimi kadencami in večkrat ne prehajajo neposredno $\mathrm{v}$ nadaljevanje, zaradi česar jih kaj lahko izdvojimo in izvajamo ločeno.

$\mathrm{Ob}$ doslej navedenem je razvidna skladateljeva težnja za slovenskim glasbenim izrazom. Več zborov in tu in tam kakšno solistično mesto zveni pristno slovensko, pri čemer se je Gerbič le včasih rahlo naslonil na

17 Prim. isto pismo. 
ljudski napev. Močnejša kot slovenska pa je v operi občeslovanska izraznost, ki je še najbližja češki. $V$ tej zvezi pa bi težko govorili o izrazitejših vplivih Dvořáka ali Smetane in še toliko manj o nekakem posnemanju teh mojstrov. Kuhačeva trditev, da je duh opere pristno slovenski, ${ }^{18}$ je le deloma pravilna in lahko velja samo za posamezne dele in ne tudi za celoto. Seveda je v Gerbičevi partituri še marsikaj, česar se v nakazanem smislu ne dá opredeliti in je izven kategorije nacionalnega. To vse kaže, da so $\mathrm{v}$ delu, ki se giblje $\mathrm{v}$ območju zgodnje in visoke romantike in se le tu in tam dotakne pozne romantike, različni stilni elementi. Ker teh skladatelj med seboj ni povsem stopil, je določena stilna heterogenost, ki ne koristi plastičnosti celotie, občutna.

Postavlja se še vprašanje uprizoritve. Po vsej priliki izvedba na gledališkem odru v prvotni obliki "Kresu» ne bi koristila, saj bi se na ta način preveč očitno pokazale vse pomanjkljivosti libreta. Ta je dramaturško tako slab, da si skoro ne moremo zamisliti uspešne predelave.

Ne glede na omenjene šibkosti moramo ugotoviti, da gre "Kresu" v naši operni literaturi iz konca 19. stoletja važno mesto. Ob Ipavčevih "TTeharskih plemičih" in Foersterjevem "Gorenjskem slavčku" predstavlja uspešno realizacijo teženj za uveljavljanjem slovenske izraznosti v naši glasbeno dramatski ustvarjalnosti in hkrati razločno distanco od bolj kozmopolitsko oziroma italijansko orientirane tvornosti Gerbičevega sodobnika V. Parme. Še važnejše je dejstvo, da pomeni „Kres» prvi poskus uvajanja pomenske motivike in širšega, svobodnejšega oblikovalnega koncepta $\mathrm{v}$ slovensko opero. Tu pa je tudi razvojni pomen Gerbičevega dela, saj nakazuje tisto, kar je dobrih deset let pozneje $\mathrm{v}$ celoti in uspešno realiziral Risto Savin.

\section{SUMMARY}

Although it is unknown when Fran Gerbič began to plot his opera Midsummer Night (Kres), it must have been at the latest in 1893, the year from which the first data in this connection have survived. As one can learn from the score, it was finished on April 5, 1896.

The libretto was written by Gerbič himself. There is no evidence in the sources, however, whether it was based on some literary work; so, it appears, that the fabula was a result of Gerbič's free imagination. Unfortunately, the composer had neither literary abilities nor an adequate feeling for the stage and was thus unable to write a text which would guarantee an integral operatic work of art. The libretto is undramatic, it contains very little action and has no real culminating point; consequently, the opera is to a considerable degree uneven as regards its quality and therefore cannot be ranked as a musically homogeneous theatrical piece.

Nevertheless, it must be pointed out that the composer's musical inventiveness has for the most part covered up the inexpressiveness of the text, with the result that many a page of the score is strongly inspired and beautiful. The vocal solos, ensembles and a number of choruses can indisputably be placed among the successful passages of the opera, thanks to the composer's affinity to lyrical moods. Especially in the duets of Zorka and Barba in the first act and of Zorka and Cilja in the second, is the composer's melodical inventiveness and expressiveness so strong that one might claim that, at these points, Gerbic does not lag behind some of his important contemporaries in the European musical world.

18 Prim. isto pismo. 
On the whole it is important that it is precisely the arias and duets in which the composer succeeded in outlining most vividly his characters - so that they come alive through the music rather than through the text.

Much weaker are the recitatives, or rather ariosos, which - sometimes due to the inexpressiveness of the vocal part and the orchestral accompaniment are all too monotonous and stereotyped. Here it appears to be especially fatal that Gerbic lacked strength when dealing with dramatically decisive passages, the main reason for which must be sought in the meagreness of the libretto. Which again does not mean that the opera has no musically convincing arioso passages, some of which can even boast of a rather broad harmonic palette.

Although Gerbič gave preference to the human voice, the importance of the orchestral accompaniment should not be overlooked. The role of the latter is to be emphasized especially in connection with instrumental introductions, intermezzos and epilogues, and, last but not least, in the use of recurrent motifs and motivic reminiscences. This gives clear proof of Gerbič's efforts to intensify his work psychologically. However, Gerbič did not make use of the principle of transforming leitmotifs symphonically, a principle so typical of late romanticism. This simpler and older manner of exploiting recurring motifs is nevertheless interesting enough, as it reveals Gerbič's concept of the opera as an expressive means, enabling the composer to unite individual parts both as regards the contents and the form, into a more organic whole. This seems to be even more important, in view of the fact that Gerbič, in spite of giving up the division of a score into rounded-off "numbers", did not quite succeed in achieving a sustained musical continuity. Arias, ensembles and choruses end in clearly emphasized cadenzas and very seldom proceed directly, for which reason they are easy to perform as individual items.

Characteristic of Midsummer Night are also the composer's efforts to achieve a Slovene musical expression. A number of choruses and some solo passages sound genuinely Slovene, although Gerbič only now and then makes use of folk tunes. Much stronger than the Slovene is a kind of a generally Slav expressiveness, repeatedly coming closest to its Czech variety. In spite of that one could hardly speak of explicit influences of Dvořák and Smetana and even less of any imitation of the great masters. Of course, in Gerbič's score there is much that cannot be categorized within the national. This shows that different stylistic elements exist in a work which moves within early and high Romanticism and only slightly touches the late phase of the latter. Having not been well casted into a whole, a certain stylistic heterogeniousness inevitably persists.

Apparently, a theatrical performance of Gerbič's Midsummer Night, especially in its original form, would be of no profit, for the deficiencies of the libretto would all too much come to the fore. Unfortuanely, dramaturgically bad as the work is, one cannot imagine a succesful revision. However, as it contains much valuable music, it is a pity to leave the score in dusty archives. All necessary cuts undertaken, perhapse the best solution would be that of a radio concert performance.

Inspite of all its deficiences Midsummer Night does occupy quite an important position in the rather modest Slovene operatic literature of the late 19th century. Together with Ipavec's The Noblemen of Teharje (Teharski plemiči) and Foerster's The Nightingale of Gorenjsko (Gorenjski slavček) it reprtesents quite a successful realization of efforts in achieving Slovene operatic expressiveness and, at the same time, a clear move away from the cosmopolitan or rather Italian oriented Gerbič's contemporary V. Parma. Much more important is the fact that Midsummer Night represents the first attempt to introduce recurring "meaningful" motifs and freer formal concepts into Slovene opera. Here lies the evolutionary role of Gerbič's work, as it indicates features which were ten years later fully and successfully realized by Risto Savin. 